\title{
Novel P-Stereogenic PCP Pincer-Aryl Ruthenium(II) Complexes and Their Use in the Asymmetric Hydrogen Transfer Reaction of Acetophenone
}

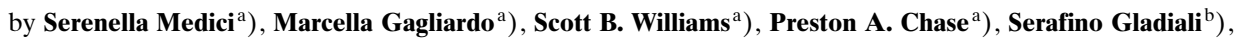 \\ Martin Lutz ${ }^{\mathrm{c}}$ ), Anthony L. Spek $\left.{ }^{\mathrm{c}}\right)^{1}$ ), Gerard P. M. van Klink ${ }^{\mathrm{a}}$ ), and Gerard van Koten*a) \\ a) Debye Institute, Department of Metal-Mediated Synthesis, Utrecht University, Padualaan 8, \\ NL-3584 CH Utrecht (phone +31-30-2533120; fax +31-30-2523615; e-mail g.vankoten@chem.uu.nl) \\ b) Dipartimento di Chimica, Università di Sassari, Via Vienna 2, I-07100 Sassari \\ c) Bijvoet Center for Biomolecular Research, Department of Crystal and Structural Chemistry, \\ Utrecht University, Padualaan 8, NL-3584 CH Utrecht
}

Dedicated to Professor André Merbach on the occasion of his 65th birthday, for his excellent contributions to the field of inorganic chemistry and for his support and friendship

Achiral P-donor pincer-aryl ruthenium complexes $\left(\left[\mathrm{RuCl}(\mathrm{PCP})\left(\mathrm{PPh}_{3}\right)\right]\right) \mathbf{4 c , d}$ were synthesized via transcyclometalation reactions by mixing equivalent amounts of [1,3-phenylenebis(methylene)]bis[diisopropylphosphine] (2c) or [1,3-phenylenebis(methylene)]bis[diphenylphosphine] (2d) and the N-donor pincer-aryl complex $\left[\mathrm{RuCl}\left\{2,6-\left(\mathrm{Me}_{2} \mathrm{NCH}_{2}\right)_{2} \mathrm{C}_{6} \mathrm{H}_{3}\right\}\left(\mathrm{PPh}_{3}\right)\right],(\mathbf{3} ;$ Scheme 2$)$. The same synthetic procedure was successfully applied for the preparation of novel chiral P-donor pincer-aryl ruthenium complexes $\left[\mathrm{RuCl}\left(\mathrm{P}^{*} \mathrm{CP} *\left(\mathrm{PPh}_{3}\right)\right]\right.$ 4a,b by reacting P-stereogenic pincer-arenes $(S, S)-[1,3$-phenylenebis(methylene) $]$ bis[(alkyl)(phenyl)phosphines] 2a,b (alkyl $={ }^{\mathrm{i}} \mathrm{Pr}$ or $\left.{ }^{t} \mathrm{Bu}, \mathrm{P}^{*} \mathrm{CHP} *\right)$ and the complex $\left[\mathrm{RuCl}\left\{2,6-\left(\mathrm{Me}_{2} \mathrm{NCH}_{2}\right)_{2} \mathrm{C}_{6} \mathrm{H}_{3}\right\}\left(\mathrm{PPh}_{3}\right)\right],(\mathbf{3}$;

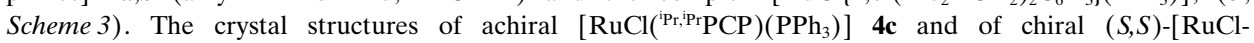
('Bu,PhPCP) $\left.\left(\mathrm{PPh}_{3}\right)\right]$ 4a were determined by X-ray diffraction (Fig. 3). Achiral $\left[\mathrm{RuCl}(\mathrm{PCP})\left(\mathrm{PPh}_{3}\right)\right]$ complexes and chiral $\left[\mathrm{RuCl}(\mathrm{P} * \mathrm{CP} *)\left(\mathrm{PPh}_{3}\right)\right]$ complexes were tested as catalyst in the $\mathrm{H}$-transfer reduction of acetophenone with propan-2-ol. With the chiral complexes, a modest enantioselectivity was obtained.

Introduction. - The interaction of multidentate phosphine ligands with late transition metals has been extensively studied since these ligands can be modularly designed to 'tune' the stereochemical and electronic properties of the corresponding metal species. Complexes of the platinum-group metals with monoanionic $\mathrm{P}$-donor pincer ligands of the type $\left[2,6-\left(\mathrm{R}_{2} \mathrm{PCH}_{2}\right)_{2} \mathrm{C}_{6} \mathrm{H}_{3}\right]^{-}\left(\mathrm{R}=\mathrm{Me},{ }^{\mathrm{i}} \mathrm{Pr},{ }^{t} \mathrm{Bu}\right.$, cyclohexyl, $\left.\mathrm{Ph}\right)[1-$ $5]$ have proven to be effective homogeneous catalysts in a number of organic transformations [6-12]. Recently, the C-chiral analogs $\left\{2,6-\left[\mathrm{R}_{2} \mathrm{PC} * \mathrm{H}\left(\mathrm{R}^{\prime}\right)\right]_{2} \mathrm{C}_{6} \mathrm{H}_{3}\right\}^{-}$ have been prepared and were shown to be catalytically active, e.g., in the asymmetric condensation of aldehydes with methyl isocyanoacetate, but exhibit only mild stereochemical induction [13]. These chiral versions of PCP pincers feature two stereogenic benzylic $\mathrm{C}$-atoms as the unique chiral element.

To achieve high enantiomer excesses, the chiral information should be situated in close vicinity to the reactive site, in this case, the metal center [14]. Therefore, a new chiral $\mathrm{P}^{*} \mathrm{CP}^{*}$ pincer ligand $\mathbf{2 a}$ was synthesized bearing the chiral information on the

1) Corresponding author for crystallographic data (phone +31-30-2532538; fax +31-30-2523940; e-mail a.1.spek@chem.uu.nl). 
$\mathrm{P}$-atom, and the corresponding platinum and palladium complexes were isolated [15]. The latter complex, along with the iridium adduct, was independently reported by other authors [16]. In both cases, however, the stereoselectivities recorded in various catalytic reactions with these complexes were low.

The high activity displayed by the $\mathrm{Ru}^{\mathrm{II}}$ complexes containing the achiral, monoanionic pincer ligand $\left[2,6-\left(\mathrm{R}_{2} \mathrm{PCH}_{2}\right)_{2} \mathrm{C}_{6} \mathrm{H}_{3}\right]^{-} \mathbf{2 d}(\mathrm{R}=\mathrm{Ph})$ in the catalytic $\mathrm{H}$ transfer reduction of ketones [9] prompted us to investigate the chemistry of the Pstereogenic $\mathrm{P}^{*} \mathrm{CP} *$ ligands in this reaction.

Herein, we report the synthesis of a new $\mathrm{P}$-stereogenic $\mathrm{P}^{*} \mathrm{CP} *$ pincer ligand $\mathbf{2 b}$ (Scheme 1) and the preparation of the novel chiral $\mathrm{Ru}^{\mathrm{II}}$ complexes $\mathbf{4 a}$ and $\mathbf{4 b}$ (Scheme 3). Complex $\mathbf{4 c}$, containing the achiral ${ }^{\mathrm{i} r} \mathrm{PCP}$ ligand $\mathbf{2 c}$, was also prepared to compare its behavior with that of its chiral counterparts, as well as the achiral ${ }^{\mathrm{Ph}} \mathrm{PCP}$ ligand 2d. Preliminary results on the catalytic activity of the prepared complexes in the H-transfer reaction of acetophenone with propan-2-ol are also presented.

Results and Discussion. - P-Stereogenic $P^{*} C P^{*}$ Ligands. The novel chiral ligand $\mathbf{2 b}$ (Scheme 1) was prepared by following the recently reported synthetic procedure applied for the synthesis of the chiral ligand 2a (Scheme 1) [15]. In the first step, the borane adduct of racemic alkyl(phenyl)monophosphine $\mathbf{1 b}$ was prepared in high yield by reaction of $\mathrm{PhPCl}_{2}$ with ${ }^{\mathrm{i}} \mathrm{PrMCl}$, followed by reduction with $\mathrm{LiAlH}_{4}$ and protection of the secondary phosphine with $\mathrm{BH}_{3} \cdot \mathrm{SMe}_{2}$. Deprotonation of the phosphine-borane adduct was achieved by reaction with $\mathrm{BuLi}$ in $\mathrm{Et}_{2} \mathrm{O}$ in the presence of $(-)$-sparteine at $-78^{\circ}$. The resulting reaction mixture was stirred for $1 \mathrm{~h}$ at $30^{\circ}$ and then allowed to react at $-78^{\circ}$ with $1,3-$ bis(bromomethyl)benzene.

Scheme 1. Synthesis of P-Stereogenic Ligands $\mathbf{2 a}$ and $\mathbf{2 b}$

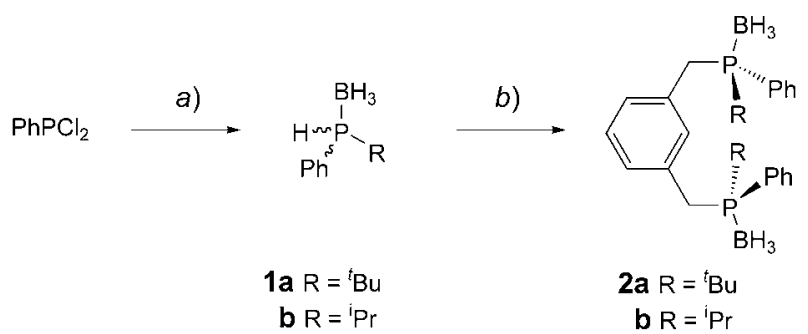

a) 1) ${ }^{t} \mathrm{BuLi}$ (for 1a) or ${ }^{i} \mathrm{PrMgCl}$ (for $\left.\mathbf{1 b}\right), \mathrm{Et}_{2} \mathrm{O},-78^{\circ}$; 2) $\mathrm{LiAlH}_{4}$, filtration; 3) $\mathrm{BH}_{3} \cdot \mathrm{SMe}_{2} . b$ ) 1) $\mathrm{BuLi}$, (-)-sparteine, $\mathrm{Et}_{2} \mathrm{O},-78^{\circ}$; 2) $\left.30^{\circ}, 1 \mathrm{~h} ; 3\right)$ 1,3-bis(bromomethyl)benzene, $-78^{\circ}$.

Chiral ligand $\mathbf{2 b}$ was obtained as a mixture of the racemate $((S, S)$ - and $(R, R)$ enantiomers) and the meso-diastereoisomer. Ligand $(S, S)$-2b was isolated in $31 \%$ yield in $77 \%$ e.e. (determined by HPLC) after fractional crystallization from $\mathrm{Et}_{2} \mathrm{O} /$ hexane, which left the contaminating meso-isomer in solution. The achiral ligands [2,6$\left.\left(\mathrm{R}_{2} \mathrm{PCH}_{2}\right)_{2} \mathrm{C}_{6} \mathrm{H}_{3}\right]^{-}\left(={ }^{\mathrm{R}} \mathrm{PCP} ; \mathrm{R}={ }^{\mathrm{i}} \mathrm{Pr}\right.$ for $\mathbf{2 c}$ and $\mathrm{Ph}$ for $\mathbf{2 d}$; (see Scheme 2$)$ were synthesized based on reported protocols [2c][3b].

Ruthenium Complexes by the Transcyclometalation Reaction. The key step of the synthesis of the achiral complexes $\left[\mathrm{RuCl}(\mathrm{PCP})\left(\mathrm{PPh}_{3}\right)\right] \mathbf{4 c}, \mathbf{d}$ is the transcyclometalation (TCM) reaction [17]. This alternative synthetic route, which represents an elegant 
methodology for the creation of a metal-C bond under relatively mild conditions, proceeds selectively and in quantitative yield. The reaction pathway (Scheme 2), which is similar to an electrophilic aromatic substitution reaction, involves the formal exchange of the tridentate monoanionic 2,6-bis(aminomethyl)phenyl ligand [2,6$\left.\left(\mathrm{Me}_{2} \mathrm{NCH}_{2}\right)_{2} \mathrm{C}_{6} \mathrm{H}_{3}\right]^{-}$of the complex [RuCl$\left.\left\{2,6-\left(\mathrm{Me}_{2} \mathrm{NCH}_{2}\right)_{2} \mathrm{C}_{6} \mathrm{H}_{3}\right\}\left(\mathrm{PPh}_{3}\right)\right]$ (3; Scheme 2) by a corresponding tridentate 2,6-bis(phosphinomethyl)phenyl ligand [2,6$\left.\left(\mathrm{R}_{2} \mathrm{PCH}_{2}\right)_{2} \mathrm{C}_{6} \mathrm{H}_{3}\right]^{-} \mathbf{2}\left(\mathrm{R}={ }^{\mathrm{i}} \mathrm{Pr}, \mathrm{Ph}\right)$. Therefore, the benzenedimethanamine is the only co-product. Its high solubility in apolar solvents allows for facile separation from the desired product 4.

Scheme 2. Synthesis of Achiral [RuCl(PCP)(PPh $)]$ Complexes $\mathbf{4 c}$ and $\mathbf{4 d}$ via the Transcyclometalation Procedure

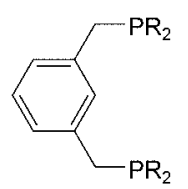

2c $R={ }^{i} \mathrm{Pr}$ d $R=P h$

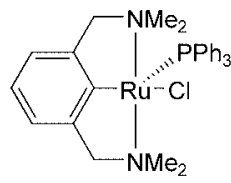

3

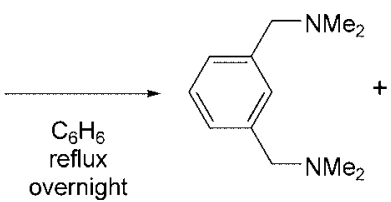

reflux
overnight

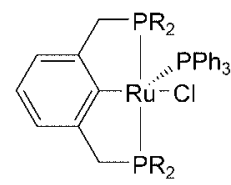

4c $\mathrm{R}={ }^{\mathrm{i}} \mathrm{Pr}$

d $R=P h$

The synthesis of $\mathbf{4 c}$ and $\mathbf{4 d}$ was achieved by means of the TCM methodology by reaction of a 1:1 molar mixture of the bis[phosphines] 2,6-( $\left.\mathrm{PR}_{2} \mathrm{PCH}_{2}\right)_{2} \mathrm{C}_{6} \mathrm{H}_{4}(\mathbf{2 c})[2 \mathrm{c}]$ and 2,6- $\left.\left(\mathrm{Ph}_{2} \mathrm{PCH}_{2}\right)_{2} \mathrm{C}_{6} \mathrm{H}_{4}\right]$ (2d) [5d], respectively, with complex [RuCl $\{2,6-$ $\left.\left.\left(\mathrm{Me}_{2} \mathrm{NCH}_{2}\right)_{2} \mathrm{C}_{6} \mathrm{H}_{3}\right\}\left(\mathrm{PPh}_{3}\right)\right](3)$ in refluxing benzene.

Both complexes were isolated in good yield as green, air-sensitive solids. Spectroscopic characterization indicated that both $\mathbf{4 c}$ and $\mathbf{4 d}$ have square-pyramidal geometry with the $\mathrm{PPh}_{3}$ ligand occupying the apical position, in accordance with the results published by Jia [5b] and Milstein [2c]. The X-ray crystal-structure determination of single crystals of $\mathbf{4} \mathbf{c}$, grown from a $\mathrm{CH}_{2} \mathrm{Cl}_{2}$ solution into which hexane vapor was allowed to diffuse slowly, confirms the features observed by ${ }^{1} \mathrm{H}-,{ }^{13} \mathrm{C}$-, and ${ }^{31} \mathrm{P}-\mathrm{NMR}$ spectroscopy in solution. A molecular drawing of complex $\mathbf{4 c}$ is depicted in Fig. 3 (vide infra), and a selection of bond lengths and angles and torsion angles is summarized in Table 1 (vide infra).

Previously, kinetic studies have been performed to gain insight into the mechanism of the TCM reaction [17b]. However, from the data obtained, it was impossible to draw definite conclusions on the reaction mechanism. The postulated intermediates 5 and $\mathbf{6}$ (Fig. 1) [18] formed during the course of the reaction after a fast, irreversible cyclometalation step, were observed in the present study, for the first time, by monitoring aliquots of a mixture containing equivalent amounts of ligand $\mathbf{2 d}$ and complex 3 in refluxing benzene by ${ }^{31} \mathrm{P}-\mathrm{NMR}$ spectroscopy. The chemical shift and multiplicity of the ${ }^{31} \mathrm{P}-\mathrm{NMR}$ signals provide an excellent probe, which allowed for the assignment of three species: the product $\left.\left[\mathrm{RuCl}\left\{2,6-\left(\mathrm{Ph}_{2} \mathrm{PCH}_{2}\right)_{2} \mathrm{C}_{6} \mathrm{H}_{3}\right]\right\}\left(\mathrm{PPh}_{3}\right)\right](\mathbf{4 d})$ and two intermediates. These intermediates, depicted in Fig. 1, are the monomer 5 and the dimer 6, which both contain $\kappa P, \kappa C, \kappa P^{\prime}$-bonded PCP and $\kappa P$-bonded PCHP ligands at a $\mathrm{Ru}^{\mathrm{II}}$ metal center. 


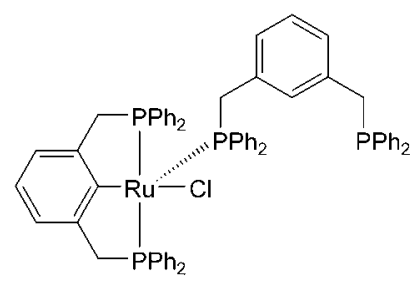

5

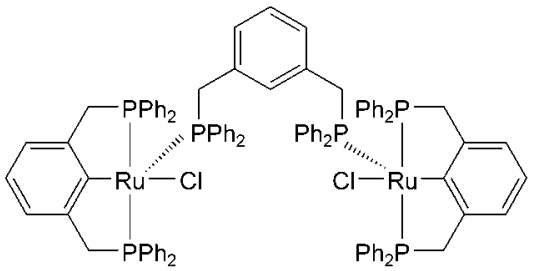

6

Fig. 1. Intermediates formed during the TCM reaction

The ${ }^{31} \mathrm{P}-\mathrm{NMR}$ spectrum of the reaction mixture $\mathbf{2 d / 3}$ after $2 \mathrm{~h}$ refluxing (Fig. 2), recorded at room temperature, shows a $d$ at $\delta(\mathrm{P}) 37.9$ (PCP P-nuclei, ${ }^{2} J(\mathrm{P}, \mathrm{P})=31.5 \mathrm{~Hz}$ ) and a $t$ at $\delta(\mathrm{P}) 83.2\left(\mathrm{PPh}_{3},{ }^{2} J(\mathrm{P}, \mathrm{P})=31.8 \mathrm{~Hz}\right)$.

These signals are characteristic for a complex in which an apical phosphine is in a cis arrangement to two magnetically equivalent $\mathrm{P}$-atoms of the cyclometalated PCP ligand in 4d $[2 \mathrm{c}][5 \mathrm{~b}][19]$. The monomer $\mathbf{5}$, present as minor compound, contains both a $\kappa P$ coordinated PCHP ligand $\left(t\right.$ at $\left.\delta(\mathrm{P}) 85.6,{ }^{2} J(\mathrm{P}, \mathrm{P})=31.5 \mathrm{~Hz}\right)$ and an $\kappa P, \kappa C, \kappa P^{\prime}$ coordinated PCP ligand $\left(d\right.$ at $\left.\delta(\mathrm{P}) 42.3,{ }^{2} J(\mathrm{P}, \mathrm{P})=33.9 \mathrm{~Hz}\right)$ coordinated to the same $\mathrm{Ru}^{\mathrm{II}}$ metal center. The $s$ at $\delta(\mathrm{P})-9.7$ can be ascribed to a dangling $\mathrm{PPh}_{2}$ moiety. The dimeric $\mathrm{Ru}^{\mathrm{II}}$ species 6 contains two $\kappa P, \kappa C, \kappa P^{\prime}$-bonded $\mathrm{Ru}^{\mathrm{II}}(\mathrm{PCP})$ units $(d$ at $\delta(\mathrm{P}) 41.9$, $\left.{ }^{2} J(\mathrm{P}, \mathrm{P})=31.5 \mathrm{~Hz}\right)$ connected through a $\mu-\kappa P, \kappa P^{\prime}$-coordinated PCHP ligand acting as a bridge $\left(t\right.$ at $\left.\delta(\mathrm{P}) 85.6,{ }^{2} J(\mathrm{P}, \mathrm{P})=31.53 \mathrm{~Hz}\right)$. Therefore, the relatively broad $t$ at $\delta(\mathrm{P}) 85.6$ has to be regarded as two superimposed $t$. The free $\mathrm{PPh}_{3}$ present in the reaction mixture $(s$ at $\delta(\mathrm{P})-3.8 \mathrm{ppm}$ ) slowly displaces the coordinated PCHP arene ligands to form complex 4d. This is evidenced by the slow disappearance of the peak corresponding to free $\mathrm{PPh}_{3}$ and the concomitant enhanced intensity of the signals of 4d. After $14 \mathrm{~h}$, the formation of $\mathbf{4 d}$ is complete.

Apparently, the rate-limiting step in the TCM reaction is not the $\mathrm{Ru}-\mathrm{C}$ bondformation or cleavage but rather the displacement of the $\kappa P$-coordinated PCHP ligand

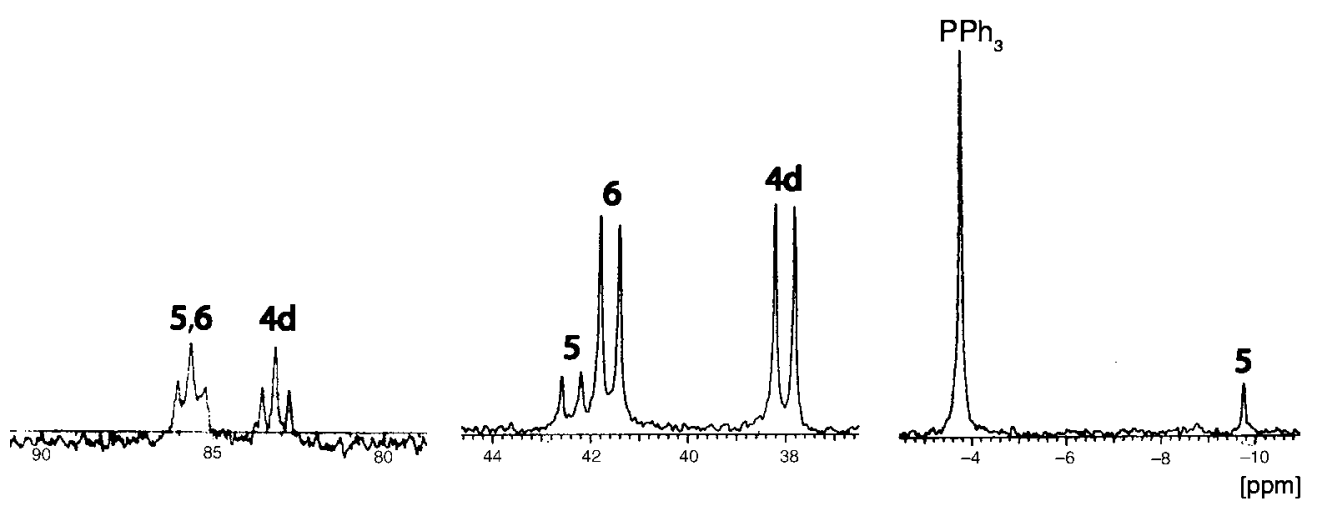

Fig. 2. Selected portions of the ${ }^{31} P$-NMR spectrum (benzene, r.t.) of the TCM reaction mixture containing equivalent amounts of ligand $\mathbf{2 d}$ and complex $\mathbf{3}$ after $2 \mathrm{~h}$ reflux 
by the free $\mathrm{PPh}_{3}$. When an excess of PCHP ligand is added to a solution of $4 \mathbf{d}$ in benzene at reflux temperature, the presence of intermediates $\mathbf{5}$ and $\mathbf{6}$ in the reaction mixture is observed in the ${ }^{31} \mathrm{P}-\mathrm{NMR}$ spectrum. This is in concert with our hypothesis and establishes that these intermediates are in equilibrium with the desired product during the TCM reaction. Recent results demonstrated that the TCM reaction is also a superior synthetic method over existing metalation procedures to introduce ruthenium metal centers in shape-persistent nanosize multi(metal-pincer) complexes [20].

The TCM procedure used for the preparation of achiral $\left[\mathrm{RuCl}(\mathrm{PCP})\left(\mathrm{PPh}_{3}\right)\right]$ was slightly modified to make it amenable for the preparation of ruthenium complexes $4 \mathbf{a}$ and $\mathbf{4 b}$ with chiral pincer ligands (Scheme 3). In a direct one-pot synthesis, the deprotection of the prepared phosphine-boranes $\mathbf{2 a}$ or $\mathbf{2 b}$ and the subsequent TCM reaction to form the chiral $\left[\mathrm{Ru}^{\mathrm{II}}\left(\mathrm{P}^{*} \mathrm{CP}^{*}\right)\right]$ complexes was performed. Deprotection of the phosphine-boranes was easily accomplished by overnight heating of a benzene solution of $\mathbf{2 a}$ or $\mathbf{2 b}$ in the presence of an excess of $\mathrm{Et}_{2} \mathrm{NH}$ at $45^{\circ}$. Williams et al. showed that these mild conditions are necessary to prevent inversion of the stereogenic Pcenters in ligand $\mathbf{2 a}$, though epimerization becomes rapid at higher temperature or over longer times [15]. [ $\left.\mathrm{RuCl}(\mathrm{NCN})\left(\mathrm{PPh}_{3}\right)\right] \mathbf{3}$ was then added, and the obtained mixture stirred for $24 \mathrm{~h}$ at $45^{\circ}$ (Scheme 3 ). The presence of $\mathrm{Et}_{2} \mathrm{NH}$, which could be subsequently removed by evaporation, did not affect the course of the TCM reaction.

Scheme 3. Synthesis of $\left[R u C l\left(P^{*} C P^{*}\right)\left(P P h_{3}\right)\right]$ Complexes $\mathbf{4 a}$ and $\mathbf{4 b}$ via the Transcyclometalation Procedure

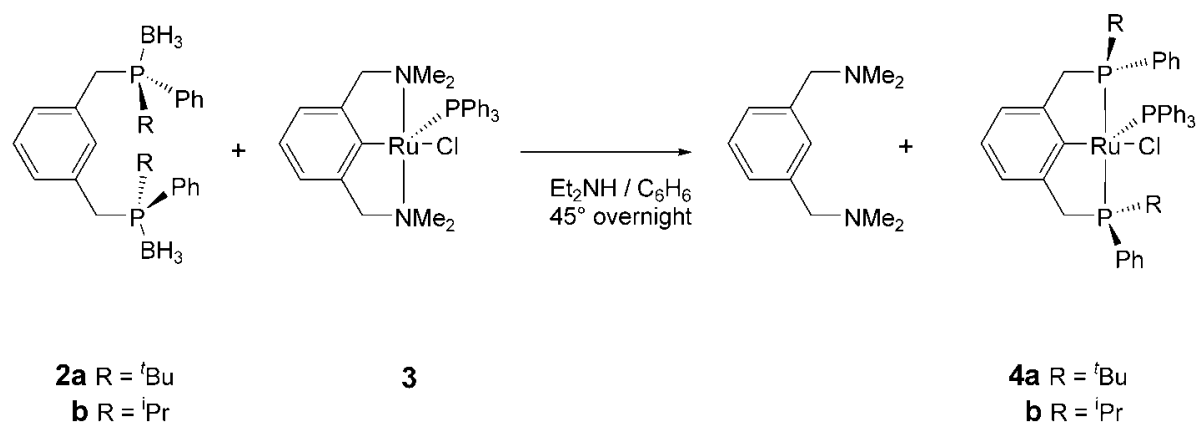

Complex 4a was isolated as a relatively air-stable, ink-blue solid, which does not require an inert atmosphere for workup. However, for long-term storage, an inert atmosphere is required. Its purification could be conveniently accomplished via column chromatography, with only a minor amount of decomposition. The ${ }^{1} \mathrm{H}-\mathrm{NMR}$ spectrum of $4 \mathbf{a}$ in $\mathrm{CD}_{2} \mathrm{Cl}_{2}$ at room temperature shows two different ${ }^{t} \mathrm{Bu}$ groups on the $\mathrm{P}$-centers and the $A B$ portion of two $A B X$ patterns for the diastereotopic benzylic protons, due to the coupling with the geminal proton and with the vicinal P-atom. In the aromatic region, broad resonances indicate dynamic behavior, which was investigated by variable-temperature NMR spectroscopy $\left(213-363 \mathrm{~K}, \mathrm{CD}_{2} \mathrm{Cl}_{2}\right)$. The dynamic process is the result of rotation of the $\mathrm{Ph}$ rings bonded to the $\mathrm{P}$-centers of the PCP ligand, and each ring rotates at a slightly different rate. By line-shape analysis of the signals assigned to the ortho-protons of these rings [21], an Eyring plot of both rotations could be constructed. The more rapidly rotating ring, distal to the $\mathrm{PPh}_{3}$ ligand, has a $\Delta H^{\ddagger}$ of 
$9.0 \pm 0.1 \mathrm{kcal} / \mathrm{mol}$ and a $\Delta S^{\ddagger}$ of $-13 \pm 1$ e.u., while the more slowly rotating ring, proximal to the $\mathrm{PPh}_{3}$ ligand, exhibits a $\Delta H^{\ddagger}$ of $10.2 \pm 0.4 \mathrm{kcal} / \mathrm{mol}$ and a $\Delta S^{\ddagger}$ of $-15 \pm 2$ e.u. The rather sizable negative entropies of activation are somewhat surprising and suggest that the molecule must rearrange considerably for rotation to occur. However, the low $\Delta H^{\ddagger}$ suggests that the $\mathrm{P}-\mathrm{Ru}$ bonds are still intact throughout the dynamic process. The $A B X$ pattern observed in the ${ }^{31} \mathrm{P}$-NMR spectrum of $\mathbf{4 a}$, recorded in $\mathrm{CD}_{2} \mathrm{Cl}_{2}$ at room temperature, clearly shows the nonequivalence of the $\mathrm{P}$-atoms of the $\mathrm{P} * \mathrm{CP} *$ ligand, which couple with the coordinated $\mathrm{PPh}_{3}$ ligand. The resonance for the $\mathrm{PPh}_{3}$ ligand appears at $\delta(\mathrm{P}) 70.3$ as a ' $d d^{\prime}(J(A, X)=35.6 \mathrm{~Hz}, J(B, X)=23.7 \mathrm{~Hz})$ due to inequivalent cis-couplings with the two $\mathrm{P}$-centers of the $\mathrm{P}^{*} \mathrm{CP} *$ ligand, while the signals assigned to the $\mathrm{P}^{*} \mathrm{CP} *$ moiety are centered at $\delta(\mathrm{P}) 40.3\left(2\right.$ ' $d d^{\prime}, J(A, B)=254.1 \mathrm{~Hz}$, in agreement with their trans-disposition around the metal). Single crystals of $4 \mathbf{4 a}$, suitable for an X-ray crystal-structure determination, were grown by slow diffusion of hexane into a $\mathrm{Et}_{2} \mathrm{O}$ solution of the complex at room temperature. A plot of the molecular structure is drawn in Fig. 3, and a selection of bond lengths and angles and torsion angles is summarized in Table 1 (vide infra). The obtained molecular structure of $\mathbf{4 a}$ confirms that the structural features observed in solution are preserved also in the solid state.

Complex $\mathbf{4 b}$ was obtained pure in low yield after several purification steps as an airsensitive, deep green, crystalline solid. Unfortunately, due to its extreme air sensitivity, satisfactory elemental and mass analyses were not obtained; the complete characterization of $\mathbf{4 b}$ is thus based mostly on ${ }^{1} \mathrm{H}$ - and ${ }^{31} \mathrm{P}-\mathrm{NMR}$ spectroscopic data. The broadened resonances observed in the aromatic region of the ${ }^{1} \mathrm{H}-\mathrm{NMR}$ spectrum $\left(\mathrm{CD}_{2} \mathrm{Cl}_{2}\right.$, room temperature $)$ are an indication of dynamic behavior very similar to that observed for 4a. Further investigations in this direction were hampered by the low stability of $\mathbf{4 b}$ under the required experimental conditions. The ${ }^{31} \mathrm{P}-\mathrm{NMR}$ spectrum

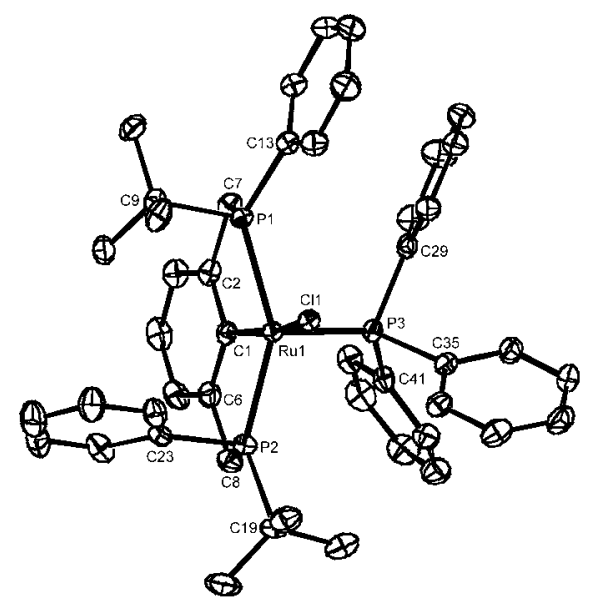

$4 a$

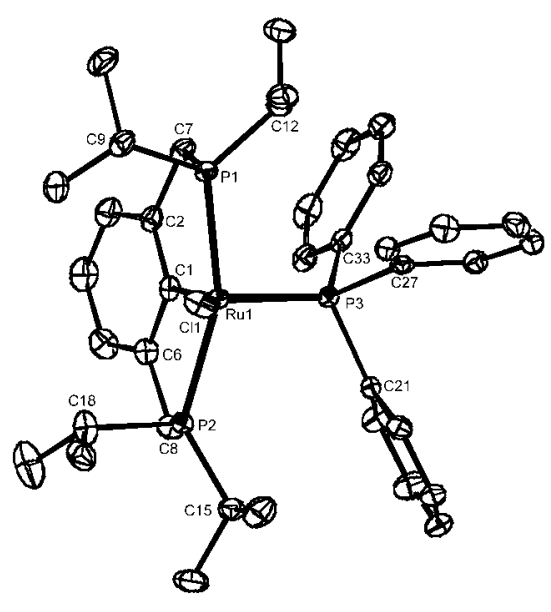

$4 \mathrm{c}$

Fig. 3. Displacement ellipsoid plot (50\% probability) of molecules $4 \mathbf{a}$ and $\mathbf{4 c}$ in the crystal 
Table 1. Selected Bond Lengths and Angles and Torsion Angles for $\mathbf{4 a}, \mathbf{4 c}$, and $\mathbf{4 d}$

\begin{tabular}{llrrr}
\hline & & 4a & 4c & 4d [5b] \\
\hline Bond lengths $[\AA]$ & $\mathrm{Ru}(1)-\mathrm{Cl}$ & $2.5036(5)$ & $2.4384(4)$ & $2.459(1)$ \\
& $\mathrm{Ru}(1)-\mathrm{C}(1)$ & $2.082(2)$ & $2.0575(17)$ & $2.070(4)$ \\
& $\mathrm{Ru}(1)-\mathrm{P}(1)$ & $2.3442(5)$ & $2.3243(5)$ & $2.297(1)$ \\
& $\mathrm{Ru}(1)-\mathrm{P}(2)$ & $2.3043(5)$ & $2.3541(5)$ & $2.284(1)$ \\
& $\mathrm{Ru}(1)-\mathrm{P}(3)$ & $2.2096(5)$ & $2.2044(5)$ & $2.196(1)$ \\
Bond angles $\left[{ }^{\circ}\right]$ & $\mathrm{Cl}(1)-\mathrm{Ru}-\mathrm{P}(1)$ & $93.248(17)$ & $91.641(16)$ & $96.1(1)$ \\
& $\mathrm{Cl}(1)-\mathrm{Ru}-\mathrm{P}(2)$ & $101.736(18)$ & $93.294(15)$ & $95.0(1)$ \\
& $\mathrm{Cl}(1)-\mathrm{Ru}(1)-\mathrm{P}(3)$ & $100.649(18)$ & $123.639(17)$ & $113.6(1)$ \\
& $\mathrm{Cl}(1)-\mathrm{Ru}(1)-\mathrm{C}(1)$ & $169.36(6)$ & $146.56(6)$ & $161.6(1)$ \\
Torsion angles $\left[{ }^{\circ}\right]$ & $\mathrm{Cl}(1)-\mathrm{Ru}(1)-\mathrm{P}(1)-\mathrm{C}(7)$ & $168.09(7)$ & $-159.66(6)$ & $\left.-175.1^{\mathrm{a}}\right)$ \\
& $\mathrm{Cl}(1)-\mathrm{Ru}(1)-\mathrm{P}(2)-\mathrm{C}(8)$ & $-171.84(8)$ & $167.76(7)$ & $\left.-172.4^{\mathrm{a}}\right)$ \\
\hline
\end{tabular}

a) Calculated from coordinates of $[5 b]$.

$\left(\mathrm{CD}_{2} \mathrm{Cl}_{2}\right.$, room temperature $)$ of $\mathbf{4} \mathbf{b}$ shows the expected $A B X$ pattern observed also for complex 4a. In this case, however, the signal assigned to the $\mathrm{PPh}_{3}$ ligand, centered at $\delta(\mathrm{P}) 86.19$ appears as a virtual $t$ due to the similar values for the couplings of the $\mathrm{PPh}_{3}$ ligand with the two $\mathrm{P}$-atoms of the $\mathrm{P} * \mathrm{CP} *$ ligand $(J(A, X)=31.7 \mathrm{~Hz}, J(B, X)=31.1 \mathrm{~Hz}$, resp.). Signals for the $\mathrm{P}^{*} \mathrm{CP}^{*}$ portion still appear as 2 ' $d d$ ' centered at $\delta(\mathrm{P}) 44.5$ $(J(A, B)=265.0 \mathrm{~Hz})$.

In Table 1, the geometric data of complexes $\mathbf{4 a}$ and $\mathbf{4 c}$ (Fig. 3 ) in the solid state are compared to the data of complex $4 \mathbf{d}$ obtained by Jia et al. [5b]. All three complexes show the $\mathrm{Ru}^{\mathrm{II}}$ centers in a distorted square-pyramidal environment embedded in the coordination pocket of the tridentate PCP ligands. The $\mathrm{PPh}_{3}$ ligands occupy the apical positions while the other two $\mathrm{P}$-centers, together with $\mathrm{Cl}$ and the $\mathrm{C}_{i p s o}$ atom, form the base of the square-pyramidal configuration. In the enantiomerically pure complex $\mathbf{4 a}$, viewed along the $\mathrm{Cl}-\mathrm{Ru}$ bond, two diagonally opposite quadrants are occupied by ${ }^{t} \mathrm{Bu}$ groups, while the other two contain the $\mathrm{Ph}$ groups. In the racemic complex $\mathbf{4 c}$, all four quadrants are occupied by ${ }^{i} \operatorname{Pr}$ groups.

The $\mathrm{Ru}-\mathrm{P}$ distances of the tridentate $\mathrm{PCP}$-pincer ligand vary significantly, more than three standard uncertainties, within one complex as well as between the three complexes $4 \mathbf{a}, \mathbf{4 c}$, and $\mathbf{4 d}[5 b]$. The $\mathrm{Ru}-\mathrm{C}(1)$ distances are quite similar in all three complexes and consistent with the distances found in a series of five-coordinate ruthenium(II) complexes containing the PCP- or NCN-pincer ligand fragment [5b]. Although the molecular geometry of $\mathbf{4 a}, \mathbf{4 c}$, and $\mathbf{4 d}$ [5b] are similar, the bulkiness of the substituents on the $\mathrm{P}$-atoms of the pincer ligands seem to influence the bond angles $\mathrm{Cl}-\mathrm{Ru}-\mathrm{P}(1), \mathrm{Cl}-\mathrm{Ru}-\mathrm{P}(2), \mathrm{Cl}-\mathrm{Ru}-\mathrm{P}(3)$, and $\mathrm{Cl}-\mathrm{Ru}-\mathrm{C}(1)$ and the torsion angles $\mathrm{Cl}-\mathrm{Ru}(1)-\mathrm{P}(1)-\mathrm{C}(7)$ and $\mathrm{Cl}-\mathrm{Ru}(1)-\mathrm{P}(1)-\mathrm{C}(8)$ (see Table 1).

Catalytic Activity. Ruthenium complexes containing pincer-aryl ligands ( $\mathrm{NCN}$ and PCP) have been shown to be catalyst precursors of outstanding activity in the reduction of ketones via the H-transfer reaction with propan-2-ol (cf. Scheme 4). For example, high conversions of cyclohexanone and turnover frequencies (TOFs) up to $27000 \mathrm{~h}^{-1}$ were observed with the triflato (=trifluoromethanesulfonato) analog of complex $\mathbf{4 d}$ as catalyst precursor [9]. For this reason, the novel chiral complexes $\mathbf{4 a}$ and $\mathbf{4 b}$, and achiral $\mathbf{4 c}$ were tested as catalyst precursors in the conversion of acetophenone (Scheme 4). 
Scheme 4. Hydrogen Transfer Reaction of Acetophenone by Ruthenium Complexes 4a-d

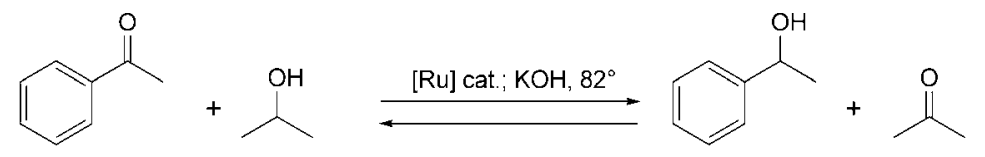

Table 2. Hydrogen-Transfer Reduction of Acetophenone. Conditions: $\mathrm{Ru}^{\mathrm{II}}$ (0.01 mmol), acetophenone $(1 \mathrm{mmol}), \mathrm{KOH}(0.2 \mathrm{mmol}),{ }^{i} \mathrm{PrOH}(10 \mathrm{ml})$, reflux temperature.

\begin{tabular}{llccc}
\hline Entry & Complex & Time $[\mathrm{h}]$ & Conv. [\%] & e.e. [\%] $\left.{ }^{\mathrm{a}}\right)$ \\
\hline 1 & $\mathbf{4 a}$ & 17 & 40 & 18 \\
2 & $\mathbf{4 b}$ & 15 & 40 & 12 \\
3 & $\mathbf{4 c}$ & 5 & $>95$ & - \\
4 & $\left.\mathbf{4 d}{ }^{\mathrm{b}}\right)$ & 0.8 & 100 & - \\
\hline
\end{tabular}

a) All the e.e.'s recorded were in favor of the $(R)$-enantiomer (HPLC). ${ }^{\mathrm{b}}$ ) See [22].

The preliminary results are summarized in Table 2, in which the values obtained with $\mathbf{4 d}$ [22] are added for comparison.

Catalytic experiments were performed by addition of the substrate to a suspension of the ruthenium complexes and $\mathrm{KOH}$ in propan-2-ol, previously heated to reflux temperature under $\mathrm{N}_{2}$. The reaction mixtures were maintained at $82^{\circ}$ during the course of the reaction. Both chiral precursors $\mathbf{4 a}$ and $\mathbf{4 b}$ having mixed aliphatic and aromatic substituents on the P-atoms were catalytically less active than the symmetric $\mathbf{4 c}$, which contains aliphatic substituents. Thus, whereas $95 \%$ conversion was obtained with $\mathbf{4 c}$ after 5 h (Entry 3), only 40\% conversion was reached with either $4 \mathbf{a}$ or $\mathbf{4 b}$ after $c a$. 15 h (Entries 1 and 2). The activities of precursors $4 \mathbf{a}$ and $\mathbf{4 b}$ at low conversion of acetophenone were comparable. Precursor 4d with four identical aromatic substituents was considerably more active in H-transfer catalysis than 4c (Entry 4). The results shown in Table 2 point to the existence of a subtle balance between electronic and steric effects in the rates of H-transfer catalyzed by $\mathbf{4 a - d}$. Electron-rich (Entry 3) and relatively electron-poor (Entry 4) ruthenium-PCP complexes both showed high activity in H-transfer from propan-2-ol to acetophenone. Fogg and co-workers recently also demonstrated high transfer rates with a flexible electron-rich ruthenium $-{ }^{\text {cy } P C P}$ complex (cy = cyclohexyl) [9b].

At low acetophenone conversion, precursors $\mathbf{4 a}$ and $\mathbf{4 b}$ induced a modest chirality transfer. As shown in Entries 1 and 2 of Table 2, e.e.s of up to $18 \%$ were observed. Apparently, the chiral pocket of the catalyst precursors allows for transfer of dihydrogen to both faces of the substrate equally well. Moreover, epimerization at the stereogenic $\mathrm{P}$-centers under the conditions applied during the catalytic experiments cannot be excluded [15].

However, after a prolonged reaction period (4 days), a complete loss of optical activity was observed with both catalyst precursors $\mathbf{4 a}$ and $\mathbf{4 b}$. It must be noted that racemization of chiral alcohols is known to occur in ruthenium-catalyzed H-transfer processes [23]. Also in our case, the degradation of chiral product into a racemic mixture of products under the reaction conditions may explain the observed loss of optical activity. Further investigations are underway in our laboratory to gain more 
insight into the effects governing H-transfer rates and chirality transfer in reactions catalyzed by $\left[\mathrm{RuX}(\mathrm{PCP})\left(\mathrm{PPh}_{3}\right)\right]$ complexes.

Conclusions. - The P-stereogenic pincer ligands $\mathbf{2 a}$ and $\mathbf{2 b}$ were used, as well as the achiral PCP ligands $\mathbf{2 c}$ and $\mathbf{2 d}$, in the transcyclometalation reaction to obtain the chiral $\left[\mathrm{RuCl}\left(\mathrm{P}^{*} \mathrm{CP} *\right)\left(\mathrm{PPh}_{3}\right)\right]$ complexes $4 \mathbf{a}$ and $\mathbf{4 b}$ and the achiral $\left[\mathrm{RuCl}(\mathrm{PCP})\left(\mathrm{PPh}_{3}\right)\right]$ complexes $\mathbf{4 c}$ and $\mathbf{4 d}$, respectively. The results show that it is also possible to prepare $\mathrm{P}$ chiral $\left[\mathrm{Ru}^{\mathrm{II}}\left(\mathrm{P}^{*} \mathrm{CP} *\right)\right]$ complexes via this route with retention of initial chirality at the $\mathrm{P}$-atoms of the $\mathrm{P}^{*} \mathrm{CHP} *$ ligand. The chiral complexes were tested as catalysts in the $\mathrm{H}$ transfer reaction of acetophenone with propan-2-ol. Preliminary results showed that although the novel chiral ruthenium complexes are moderately active, the chiral induction is lost upon prolonged reaction.

Dr. H. P. Dijkstra and H. Kleijn are kindly thanked for helpful discussions, and J. de Pater for NMR experimental assistance. This work was supported in part (M. L., A. L. S.) by The Netherlands Foundation for Chemical Sciences $(C W)$ with financial aid from the Netherlands Organization for Scientific Research $(N W O)$ and (P. A. C.) the Natural Sciences and Engineering Research Council of Canada.

\section{Experimental Part}

General. [RuCl(NCN) $\left.\left(\mathrm{PPh}_{3}\right)\right] \mathbf{3}$ [24], [ $\left.\mathrm{RuCl}\left({ }^{\mathrm{Ph}} \mathrm{PCP}\right)\left(\mathrm{PPh}_{3}\right)\right]$, 4d [17b], 2a [15], ${ }^{\mathrm{i} r} \mathrm{PCP}[2 \mathrm{c}]$, and ${ }^{\mathrm{Ph}} \mathrm{PCP}[3 \mathrm{~b}]$ were prepared according to literature procedures. All enantiomer excesses were determined by chiral HPLC analysis (Daicel Chiralcel-OD column; flow rate $1.0 \mathrm{ml} / \mathrm{min}$; hexane/ $\mathrm{PrOH} / \mathrm{AcOEt} 96: 2: 2$ ). All reactions were carried out under dry $\mathrm{N}_{2}$ by using standard Schlenk techniques unless specified otherwise. Purchased chemicals (Acros and Aldrich) were used without further purification. Solvents were dried by standard procedures, distilled, and stored under $\mathrm{N}_{2}$. $\mathrm{Et}_{2} \mathrm{NH}$ was degassed before use by the freeze-pump-thaw technique. ${ }^{1} \mathrm{H}-,{ }^{13} \mathrm{C}$ - and ${ }^{31} \mathrm{P}-\mathrm{NMR}$ Spectra: Bruker AC200 or Varian Unity-INOVA-300 NMR spectrometer; chemical shifts $\delta$ in $\mathrm{ppm}$ referenced to the residual solvent signal $\left({ }^{1} \mathrm{H}\right.$ and $\left.{ }^{13} \mathrm{C}\right)$ and a capillary containing $85 \% \mathrm{H}_{3} \mathrm{PO}_{4}\left({ }^{31} \mathrm{P}\right)$; coupling constants $J$ in $\mathrm{Hz}$.

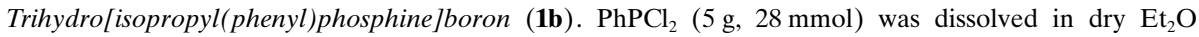
$(70 \mathrm{ml})$ and stirred at $-78^{\circ}$ for $15 \mathrm{~min}$. Subsequently, $2 \mathrm{M}{ }^{\mathrm{i}} \mathrm{PrMgCl} \mathrm{Et}_{2} \mathrm{O}(15.4 \mathrm{ml}, 30.8 \mathrm{mmol})$ was added dropwise via syringe within $15 \mathrm{~min}$. The obtained suspension was stirred at $-78^{\circ}$ for $0.5 \mathrm{~h}$, then allowed to warm to r.t., and stirred for an additional $1.5 \mathrm{~h}$. The mixture was filtered through a sintered-glass filter and was added within $45 \mathrm{~min}$ to a suspension of $\mathrm{LiAlH}_{4}(1.17 \mathrm{~g}, 30.8 \mathrm{mmol})$ in $\mathrm{Et}_{2} \mathrm{O}(30 \mathrm{ml})$ cooled at $-78^{\circ}$. After stirring for $1 \mathrm{~h}$, the mixture was allowed to warm to r.t., quenched carefully with degassed $\mathrm{H}_{2} \mathrm{O}$, and filtered through a glass filter. $\mathrm{BH}_{3} \cdot \mathrm{SMe}_{2}(94 \% ; 10.6 \mathrm{ml}, 140 \mathrm{mmol})$ was added by syringe at $0^{\circ}$, and the soln. was stirred at r.t. for $0.5 \mathrm{~h}$ before being carefully poured into a mixture of ice $(100 \mathrm{~g})$ and $4 \mathrm{M} \mathrm{HCl}(50 \mathrm{ml})$. The aq. layer was washed twice with $\mathrm{Et}_{2} \mathrm{O}(2 \times 50 \mathrm{ml})$, the combined org. phase washed with $\mathrm{H}_{2} \mathrm{O}(50 \mathrm{ml})$ and brine $(50 \mathrm{ml})$, dried $\left(\mathrm{MgSO}_{4}\right)$, and evaporated, and the residue dissolved in $\mathrm{CH}_{2} \mathrm{Cl}_{2}$ and filtered through silica gel. Evaporation gave $\mathbf{1 b}(3.0 \mathrm{~g}$, $64 \%$ ). Dense oil. ${ }^{1} \mathrm{H}-\mathrm{NMR}\left(300 \mathrm{MHz}, \mathrm{CDCl}_{3}\right)$ : 0.74 (br. $\left.q,{ }^{1} J(\mathrm{H}, \mathrm{B})=96,4 \mathrm{H}, \mathrm{BH}_{3}\right) ; 1.15(d q, J(\mathrm{H}, \mathrm{H})=7.2, J$ $\left.(\mathrm{H}, \mathrm{P})=9.0,3 \mathrm{H}, \mathrm{Me}_{2} \mathrm{CH}\right) ; 1.18\left(d q, J(\mathrm{H}, \mathrm{P})=7.4, J(\mathrm{H}, \mathrm{P})=9.6,3 \mathrm{H}, \mathrm{Me}_{2} \mathrm{CH}\right) ; 2.23\left(m, \mathrm{Me}_{2} \mathrm{CH}\right) ; 5.25(d d q$, $\left.{ }^{3} J(\mathrm{H}, \mathrm{H})=4.0,{ }^{2} J(\mathrm{H}, \mathrm{B})=6.6,{ }^{1} J(\mathrm{H}, \mathrm{P})=365.5, \mathrm{HP}\right) ; 7.40-7.57$ ( $m, 3$ arom. H $) ; 7.62-7.71$ ( $m, 2$ arom. H). ${ }^{13} \mathrm{C}-\mathrm{NMR}\left(300 \mathrm{MHz}, \mathrm{CDCl}_{3}\right): 18.04\left(d,{ }^{2} J(\mathrm{C}, \mathrm{P})=41.8, M e_{2} \mathrm{C}\right) ; 29.71\left(d,{ }^{1} J(\mathrm{C}, \mathrm{P})=34.6, \mathrm{Me}_{2} \mathrm{CH}\right) ; 125.05(d$, $\left.{ }^{1} J(\mathrm{C}, \mathrm{P})=53.4, \mathrm{C}_{i p s o}\right) ; 129.11\left(d,{ }^{3} J(\mathrm{C}, \mathrm{P})=9.7,2 \mathrm{C}_{m}\right) ; 131.90\left(d,{ }^{4} J(\mathrm{C}, \mathrm{P})=2.4, \mathrm{C}_{p}\right) ; 133.65\left(d,{ }^{2} J(\mathrm{C}, \mathrm{P})=8.8, \mathrm{C}_{o}\right)$. ${ }^{31} \mathrm{P}-\mathrm{NMR}\left(200 \mathrm{MHz}, \mathrm{CDCl}_{3}\right.$ ): 28.85 (br. $m$ ). Anal. calc. for $\mathrm{C}_{9} \mathrm{H}_{16} \mathrm{BP}$ (166.01): $\mathrm{C}$ 65.12, H 9.72, P 18.66; found C 65.06, H 9.64, P 18.49.

Hexahydro $\left\{\mu-\left\{\left[\mathrm{P}(\mathrm{S}), \mathrm{P}^{\prime}(\mathrm{S})\right]-[1,3-\right.\right.$ phenylenebis (methylene) $]$ bis [isopropyl(phenyl)phosphine- $\left.\left.\left.\kappa \mathrm{P}\right]\right\}\right\}$ diboron (2b). BuLi $(1.6 \mathrm{M}$ in hexane; $18.3 \mathrm{ml}, 11.5 \mathrm{mmol})$ was added dropwise via syringe to a soln. of $\mathbf{1 b}(2.0 \mathrm{~g}$, $12.05 \mathrm{mmol})$ in dry $\mathrm{Et}_{2} \mathrm{O}(50 \mathrm{ml})$, cooled at $-78^{\circ}$. The mixture was stirred at low temp. for $15 \mathrm{~min}$. Then $(-)-$ sparteine $(3.67 \mathrm{~g}, 15.7 \mathrm{mmol})$ was added via syringe, the cooling bath removed, and the mixture allowed to rise to r.t. within $1 \mathrm{~h}$. The mixture was placed in a warm-water bath $\left(\mathrm{ca} .30^{\circ}\right)$ for $1 \mathrm{~h}$, after which the temp. was lowered to $-78^{\circ}$ and 1,3-bis(bromomethyl)benzene $(1.43 \mathrm{~g}, 5.4 \mathrm{mmol})$ added as soln. in $\mathrm{Et}_{2} \mathrm{O}(20 \mathrm{ml})$. The mixture was stirred for $3 \mathrm{~h}$ while the temp. was slowly raised to $-20^{\circ}$ and subsequently placed in the freezer 
$\left(-30^{\circ}\right)$ overnight. Then, $5 \% \mathrm{H}_{2} \mathrm{SO}_{4}$ soln. $(100 \mathrm{ml})$ was slowly added, the aq. layer washed with $\mathrm{CH}_{2} \mathrm{Cl}_{2}(3 \times$ $50 \mathrm{ml})$, the combined org. layer washed with aq. $\mathrm{Na}_{2} \mathrm{CO}_{3}$ soln. $(100 \mathrm{ml})$ and brine $(100 \mathrm{ml})$ and evaporated, and the residue washed with hexanes/ $\mathrm{Et}_{2} \mathrm{O} 3: 1: \mathbf{2 b}(730 \mathrm{mg}, 31 \%)$. White solid as fine powder. HPLC: $(S, S)$ enantiomer in $77 \%$ e.e. $[\alpha]_{\mathrm{D}}^{21}=+8\left(c=1, \mathrm{CHCl}_{3}\right) .{ }^{1} \mathrm{H}-\mathrm{NMR}\left(300 \mathrm{MHz}, \mathrm{CDCl}_{3}\right): 0.05-1.80\left(\right.$ br. $\left.q, \mathrm{BH}_{3}\right) ; 0.99$ $\left(d d,{ }^{3} J(\mathrm{H}, \mathrm{H})=6.9,{ }^{3} \mathrm{~J}(\mathrm{P}, \mathrm{H})=15.6,6 \mathrm{H}, M e_{2} \mathrm{CH}\right) ; 1.31\left(d d,{ }^{3} J(\mathrm{H}, \mathrm{H})=7.2,{ }^{3} J(\mathrm{P}, \mathrm{H})=15.9,6 \mathrm{H}, \mathrm{Me}_{2} \mathrm{CH}\right) ; 2.33$ (sept. $\left.,{ }^{2} J(\mathrm{H}, \mathrm{H})=6.9,2 \mathrm{Me}_{2} C H\right) ; 3.17\left(2\right.$ ' $d d$ ', $A B$ of $A B X^{1} J\left(\mathrm{H}_{\mathrm{a}}, \mathrm{H}_{\mathrm{b}}\right)=14.2,{ }^{2} J\left(\mathrm{H}_{\mathrm{a}}, \mathrm{P}\right)=9.3,{ }^{2} J\left(\mathrm{H}_{\mathrm{b}}, \mathrm{P}\right)=12.0,2$ $\left.\mathrm{CH}_{2}\right) ; 6.54(d d, J=2.0, J=7.5, \mathrm{H}-\mathrm{C}(4), \mathrm{H}-\mathrm{C}(6)) ; 6.80(d, J=2, \mathrm{H}-\mathrm{C}(5)) ; 6.85(s, \mathrm{H}-\mathrm{C}(2)) ; 7.36(d d, J=1.8$, 7.5, $\left.4 \mathrm{H}_{o}(\mathrm{PhP})\right) ; 7.44-7.50\left(m, 4 \mathrm{H}_{m}(\mathrm{PhP}), 2 \mathrm{H}_{p}(\mathrm{PhP})\right) .{ }^{13} \mathrm{C}-\mathrm{NMR}\left(300 \mathrm{MHz}, \mathrm{CDCl}_{3}\right): 17.01\left(s, 2 \mathrm{Me}_{2} \mathrm{C}\right) ; 22.15$ $\left(d,{ }^{1} J(\mathrm{C}, \mathrm{P})=34.8,2 \mathrm{Me}_{2} C \mathrm{H}\right) ; 32.07\left(d,{ }^{1} J(\mathrm{C}, \mathrm{P})=30.5,2 \mathrm{CH}_{2}\right) ; 126.70\left(d,{ }^{1} J(\mathrm{C}, \mathrm{P})=50.1,2\right.$ arom. $\mathrm{C}$ (quat. $\left.)\right)$; $128.34\left(d t,{ }^{2} J(\mathrm{C}, \mathrm{P})=47.2,{ }^{4} J(\mathrm{C}, \mathrm{P})=2.4, \mathrm{C}(1), \mathrm{C}(3)\right) ; 128.60\left(d,{ }^{3} J(\mathrm{C}, \mathrm{P})=9.1,4 \mathrm{C}_{m}(\mathrm{PhP})\right) ; 128.70(s, \mathrm{C}(5))$; $131.30\left(t,{ }^{3} J(\mathrm{C}, \mathrm{P})=3.8, \mathrm{C}(2)\right) ; 131.51\left(d,{ }^{4} J(\mathrm{C}, \mathrm{P})=2.4,2 \mathrm{C}_{p}(\mathrm{PhP})\right) ; 132.93(d d, J=2.4,6.1, \mathrm{C}(4), \mathrm{C}(5), \mathrm{C}(6))$; $133.35\left(d,{ }^{2} J(\mathrm{C}, \mathrm{P})=8.0,4 \mathrm{C}_{o}(\mathrm{PhP})\right) .{ }^{31} \mathrm{P}-\mathrm{NMR}\left(200 \mathrm{MHz}, \mathrm{CDCl}_{3}\right): 28.03$ (br. $\left.m\right)$. Anal. calc. for $\mathrm{C}_{26} \mathrm{H}_{38} \mathrm{~B}_{2} \mathrm{P}_{2}$ (434.16): C 71.93, H 8.82, P 14.27; found: C 71.86, H 8.80, P 14.34.

$\{2,6-B i s\{\{[\mathrm{P}(\mathrm{S})]$-(tert-butyl)phenylphosphino- $\kappa \mathrm{P}\}$ methyl\}phenyl $-\kappa \mathrm{C}\}$ chloro (triphenylphosphine)ruthenium (4a). Phosphine - borane $2 \mathbf{a}(173 \mathrm{mg}, 0.375 \mathrm{mmol})$ was heated overnight $\left(45^{\circ}\right)$ in a mixture of $\mathrm{Et}_{2} \mathrm{NH}$ and benzene. Complex [ $\left.\mathrm{RuCl}(\mathrm{NCN})\left(\mathrm{PPh}_{3}\right)\right] \mathbf{3}(246 \mathrm{mg}, 0.417 \mathrm{mmol})$ was subsequently added, and the heating was continued for $48 \mathrm{~h}$ (deep purple $\rightarrow$ deep blue). The volatiles were removed under high vacuum and the obtained solid residue washed with cold pentane, dissolved in $\mathrm{Et}_{2} \mathrm{O}$ and purified by column chromatography: $\mathbf{4 a}$ (200 $\mathrm{mg}$, $60 \%)$. Ink-blue air-stable solid. ${ }^{1} \mathrm{H}$-NMR $\left(300 \mathrm{MHz},\left(\mathrm{D}_{8}\right)\right.$-toluene $): 0.48\left(d,{ }^{3} J(\mathrm{H}, \mathrm{P})=12.3,1{ }^{ } \mathrm{Bu}\right) ; 1.35(d$, $\left.{ }^{3} J(\mathrm{H}, \mathrm{P})=13.3,1{ }^{~} \mathrm{Bu}\right) ; 1.96\left({ }^{\prime} d d^{\prime}, A\right.$ of $\left.A B X,{ }^{2} J(\mathrm{H}, \mathrm{H})=16.0,{ }^{2} J(\mathrm{H}, \mathrm{P})=3.6,1 \mathrm{H}, \mathrm{CH}_{2}\right) ; 2.94\left({ }^{\prime} d d^{\prime}, A^{\prime}\right.$ of $A^{\prime} B^{\prime} X^{\prime}$, $\left.{ }^{2} J(\mathrm{H}, \mathrm{H})=15.9,{ }^{2} J(\mathrm{H}, \mathrm{P})=8.7,1 \mathrm{H}, \mathrm{CH}_{2}\right) ; 3.29\left(' d d ', B\right.$ of $\left.A B X,{ }^{2} J(\mathrm{H}, \mathrm{H})=16.0,{ }^{2} J(\mathrm{H}, \mathrm{P})=14.0,1 \mathrm{H}, \mathrm{CH}_{2}\right) ; 3.35$ (' $t$ ', $B^{\prime}$ of $\left.A^{\prime} B^{\prime} X^{\prime},{ }^{2} J(\mathrm{H}, \mathrm{H})={ }^{2} J(\mathrm{H}, \mathrm{P})=15.9,1 \mathrm{H}, \mathrm{CH}_{2}\right) ; 6.48\left(\right.$ br., $\left.1 \mathrm{H}_{o}(\mathrm{PhP})\right) ; 6.80\left(d t, J=7.2,2.1,4 \mathrm{H}_{m}(\mathrm{PhP}), 2\right.$ $\left.\mathrm{H}_{p}(\mathrm{PhP})\right) ; 6.94(t d, J=7.2,1.3, \mathrm{H}-\mathrm{C}(3), \mathrm{H}-\mathrm{C}(4), \mathrm{H}-\mathrm{C}(5)) ; 6.99-7.10\left(m, 6 \mathrm{H}_{m}\left(\mathrm{Ph}_{3} \mathrm{P}\right), 3 \mathrm{H}_{p}\left(\mathrm{Ph}_{3} \mathrm{P}\right)\right) ; 7.56(t d$, $\left.J=11.3,3.3,6 \mathrm{H}_{o}\left(\mathrm{Ph}_{3} \mathrm{P}\right)\right) ; 8.30$ (br., $\left.2 \mathrm{H}_{o}(\mathrm{PhP})\right)$; 9.43 (br. $\left.1 \mathrm{H}_{o}(\mathrm{PhP})\right) .{ }^{13} \mathrm{C}-\mathrm{NMR}\left(300 \mathrm{MHz}, \mathrm{CDCl}_{3}\right)$ : $27.55(d$, $\left.J=4.2,1 \mathrm{Me}_{3} \mathrm{C}\right) ; 27.95\left(d, J=4.3,1 \mathrm{Me}_{3} \mathrm{C}\right) ; 31.63(d, J=17.6,1 \mathrm{C}$ (quat. )); $34.36(d d, J=11.5,7.3,1 \mathrm{C}$ (quat. $)$ ); $35.03\left(d, J=25.5,1 \mathrm{CH}_{2}\right) ; 36.43\left(d, J=24.9,1 \mathrm{CH}_{2}\right) ; 120.80(d, J=16.5, \mathrm{C}(3)$ or $\mathrm{C}(5)) ; 121.65(s, \mathrm{C}(4)) ; 123.26$ $(d, J=14.6, \mathrm{C}(3)$ or $\mathrm{C}(5)) ; 126.48\left(d, J=9.7,5 \mathrm{C}_{m}\left(\mathrm{Ph}_{3} \mathrm{P}\right)\right) ; 127.64\left(d, J=7.3,4 \mathrm{C}_{m}(\mathrm{PhP})\right) ; 128.51\left(s, 2 \mathrm{C}_{p}(\mathrm{PhP})\right)$; $128.93\left(s, 3 \mathrm{C}_{p}\left(\mathrm{Ph}_{3} \mathrm{P}\right)\right) ; 129.35\left(d d, J=10.3,1.8,4 \mathrm{C}_{o}(\mathrm{PhP})\right) ; 134.77\left(d, J=9.7,6 \mathrm{C}_{o}\left(\mathrm{Ph}_{3} \mathrm{P}\right)\right) ; 134.85(d, J=13.0,2$ $\left.\mathrm{C}_{\text {ipso }}(\mathrm{PhP})\right) ; 136.42\left(d^{\prime} t\right.$ ', $\left.J=49.7,2.4,3 \mathrm{C}_{\text {ipso }}\left(\mathrm{Ph}_{3} \mathrm{P}\right)\right) ; 150.35(d, J=9.1, \mathrm{C}(2)$ or $\mathrm{C}(6)) ; 152.67(d d, J=15.75,2.7$, $\mathrm{C}(2)$ or $\mathrm{C}(6))$; $173.92(d, J=17.6, \mathrm{C}(1)) .{ }^{31} \mathrm{P}-\mathrm{NMR}\left(200 \mathrm{MHz},\left(\mathrm{D}_{6}\right)\right.$ benzene): 40.28 (2 ' $d d$ ' $A B$ of $A B X$, $J(A, X)=35.6, J(B, X)=23.7, J(A, B)=254.1) ; 70.33$ (' $d d$ ', $X$ of $A B X, J(A, X)=35.6, J(B, X)=23.7)$. Anal. calc. for $\mathrm{C}_{46} \mathrm{H}_{50} \mathrm{ClP}_{3} \mathrm{Ru}$ (832.38): $\mathrm{C} 66.38, \mathrm{H}$ 6.05, P 11.16; found: $\mathrm{C} 66.42, \mathrm{H}$ 6.12, P 11.21.

$\{2,6-B i s\{\{[\mathrm{P}(\mathrm{S})]-$-isopropyl(phenyl)phosphino- $\mathrm{k} \mathrm{P}\}$ methyl\}phenyl- $\kappa \mathrm{C}\}$ chloro(triphenylphosphine) ruthenium (4b). As described for $\mathbf{4 a}$, with $\mathbf{2 b}(260 \mathrm{mg}, 0.6 \mathrm{mmol})$ and $\mathbf{3}(350 \mathrm{mg}, 0.6 \mathrm{mmol})$ (deep purple $\rightarrow$ deep green). The volatiles were removed in vacuo to give an air-sensitive green solid, which was dissolved in $\mathrm{Et}_{2} \mathrm{O}$. The soln. was filtered through a sintered-glass filter and evaporated: $80 \mathrm{mg}(16 \%)$ of $\mathbf{4 b}$. No further purification was possible since $4 \mathbf{b}$ is soluble in all standard org. solvents. ${ }^{1} \mathrm{H}-\mathrm{NMR}\left(300 \mathrm{MHz},\left(\mathrm{D}_{6}\right)\right.$ benzene): 0.17 ( $d d$, $\left.{ }^{3} J(\mathrm{H}, \mathrm{P})=13.8,{ }^{3} J(\mathrm{H}, \mathrm{H})=7.2,3 \mathrm{H}, \mathrm{Me}_{2} \mathrm{CH}\right) ; 0.52\left(d d,{ }^{3} J(\mathrm{H}, \mathrm{P})=11.4,{ }^{3} J(\mathrm{H}, \mathrm{H})=7.2,3 \mathrm{H}, M e_{2} \mathrm{CH}\right) ; 0.71(d d$, $\left.{ }^{3} J(\mathrm{H}, \mathrm{P})=13.8,{ }^{3} J(\mathrm{H}, \mathrm{H})=7.2,3 \mathrm{H}, M e_{2} \mathrm{CH}\right) ; 1.67\left(d d,{ }^{3} J(\mathrm{H}, \mathrm{P})=11.4,{ }^{3} J(\mathrm{H}, \mathrm{H})=7.2, J=1,1,3 \mathrm{H}, M e_{2} \mathrm{CH}\right) ; 1.91$ $\left(\right.$ sept. $\left.{ }^{3} J(\mathrm{H}, \mathrm{H})=7.2,1 \mathrm{Me}_{2} C H\right) ; 2.02\left({ }^{\prime} d d\right.$ ', $A$ of $\left.A B X,{ }^{1} J(\mathrm{H}, \mathrm{H})=16.5,{ }^{2} J(\mathrm{H}, \mathrm{P})=4.2,1 \mathrm{H}, \mathrm{CH}_{2}\right) ; 2.18$ (dsept, $\left.{ }^{3} J(\mathrm{H}, \mathrm{H})=7.2,{ }^{2} J(\mathrm{H}, \mathrm{P})=2.4,1 \mathrm{Me}_{2} \mathrm{CH}\right) ; 2.39\left({ }^{\prime} d d^{\prime}, A^{\prime}\right.$ of $\left.A^{\prime} B^{\prime} X^{\prime},{ }^{1} J(\mathrm{H}, \mathrm{H})=16.5,{ }^{2} J(\mathrm{H}, \mathrm{P})=7.2,1 \mathrm{H}, \mathrm{CH}_{2}\right) ; 3.01$ (' $d d^{\prime}, B^{\prime}$ of $\left.A^{\prime} B^{\prime} X^{\prime},{ }^{1} J(\mathrm{H}, \mathrm{H})=16.5,{ }^{2} J(\mathrm{H}, \mathrm{P})=13.2,1 \mathrm{H}, \mathrm{CH}_{2}\right) ; 3.37$ (' $d d^{\prime}, B$ of $A B X,{ }^{1} J(\mathrm{H}, \mathrm{H})=16.5,{ }^{2} J(\mathrm{H}, \mathrm{P})=$ $\left.13.2,1 \mathrm{H}, \mathrm{CH}_{2}\right) ; 6.73(d t, J=2.3, J=7.5,3$ arom. $\mathrm{H}) ; 6.81(t d, J=1.8, J=7.2,1$ arom. $\mathrm{H}) ; 6.93-7.01$ (series of $m$, 12 arom. $\mathrm{H}) ; 7.35$ (br., 2 arom. $\mathrm{H}) ; 7.48(\mathrm{~m}, 3$ arom. $\mathrm{H}) ; 7.71(d d d, J=1.5,8.0,11.7,3$ arom. $\mathrm{H}) ; 7.79(d t, J=1.8$, 8.0, 1 arom. H); 8.22 ( $d t, J=1.5,8.0,1$ arom. H). ${ }^{31}$ P-NMR (200 MHz, $\left(\mathrm{D}_{6}\right)$ benzene $): 44.49$ (2 ' $d d^{\prime} ; A B$ of $A B X$, $J(A, X)=31.67, J(B, X)=31.07, J(A, B)=265.0) ; 86.19\left({ }^{\circ} t, X\right.$ of $\left.A B X, J(A, X)=J(B, X)=31.50\right)$.

$\{2,6-$ Bis [(diisopropylphosphino- $\kappa \mathrm{P})$ methyl]phenyl- $\kappa \mathrm{C}\}$ chloro(triphenylphosphine)ruthenium (4c). To a soln. of [ $\left.\mathrm{RuCl}(\mathrm{NCN})\left(\mathrm{PPh}_{3}\right)\right] \mathbf{3}(425 \mathrm{mg}, 0.72 \mathrm{mmol})$ in benzene $(15 \mathrm{ml})$ was added a soln. of ${ }^{\mathrm{Pr}} \mathrm{PCP}(258 \mathrm{mg}$, $0.76 \mathrm{mmol})$ in benzene $(15 \mathrm{ml})$. The mixture was stirred for $15 \mathrm{~h}$ under reflux and then evaporated to give an airsensitive green solid. The solid was washed with $\mathrm{Et}_{2} \mathrm{O}(3 \times 5 \mathrm{ml})$ and then dissolved in benzene, and the soln. filtered through a sintered-glass filter and evaporated: pure $4 \mathbf{c}(300 \mathrm{mg}, 57 \%)$. Green powder. NMR: in agreement with values previously reported [2d].

Crystal-Structure Determinations. X-Ray intensities were measured on a Nonius KappaCCD diffractometer with rotating anode $\left(\mathrm{Mo}-K_{\alpha}, \lambda 0.71073 \AA\right.$ ) at $150 \mathrm{~K}$. The structures were solved with automated Patterson methods [25] (4a) or direct methods [26] (4c) and refined with SHELXL97 [27] against $F^{2}$ of all reflections. 
Structure calculations, drawings and checking for higher symmetry was performed with the PLATON package [28].

Data of 4a: $\mathrm{C}_{46} \mathrm{H}_{50} \mathrm{ClP}_{3} \mathrm{Ru}, M_{\mathrm{r}}=832.29$; black block, $0.30 \times 0.30 \times 0.15 \mathrm{~mm}$; tetragonal, $P 4_{1}($ No. 76$), a=$

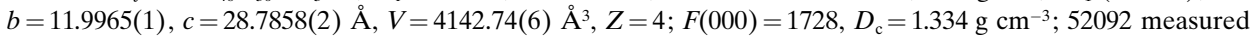
reflections, 9482 unique reflections $\left(R_{\text {int }}=0.038\right)$; absorption correction based on multiple measured reflections (PLATON [22], routine MULABS, $\mu=0.59 \mathrm{~mm}^{-1}$, correction range $\left.0.86-0.90\right)$; 540 refined parameters, 1 restraint; Flack parameter [29] $x=-0.008(13) ; R(I>2 \sigma(I)): R_{1}=0.0230, w R_{2}=0.0560 . R\left(\right.$ all data): $R_{1}=$ $0.0254, w R_{2}=0.0571 ; S=1.018$; residual electron density $(\min / \max )=-0.39 / 0.70 \mathrm{e} / \AA^{3}$.

Data of 4c: $\mathrm{C}_{38} \mathrm{H}_{50} \mathrm{ClP}_{3} \mathrm{Ru}, M_{\mathrm{r}}=736.21$; dark red block, $0.33 \times 0.21 \times 0.15 \mathrm{~mm}^{3}$; triclinic, $P \overline{1}$ (No. 2$) ; a=$ $10.4440(1), b=10.9182(1), c=17.6424(2) \AA, \alpha=72.8243(4), \beta=81.0784(4), \gamma=66.7457(5)^{\circ}, V=1764.20(3) \AA^{3}$, $Z=2 ; F(000)=768, D_{\mathrm{c}}=1.386 \mathrm{~g} \mathrm{~cm}^{-3} ; 28439$ measured reflections, 8037 unique reflections $\left(R_{\text {int }}=0.042\right)$; absorption correction based on multiple measured reflections (PLATON [22], routine MULABS, $\mu=$ $0.68 \mathrm{~mm}^{-1}$, correction range $\left.0.84-0.88\right) ; 484$ refined parameters, 0 restraints; $R(I>2 \sigma(I)): R_{1}=0.0265$, $w R_{2}=0.0608 ; R$ (all data): $R_{1}=0.0329 ; w R_{2}=0.0635 ; S=1.046 ;$ residual electron density $(\min / \max )=-0.80 /$ $1.16 \mathrm{e} / \AA^{3}$.

CCDC-253863 (4a) and 253864 (4c) contain the supplementary crystallographic data for this paper. These data can be obtained free of charge via www.ccdc.cam.ac.uk/conts/retrieving.html (or from the CCDC, 12 Union Road, Cambridge CB21EZ, UK; fax: +441223336033; e-mail: deposit@ccdc.cam.ac.uk).

Hydrogen-Transfer Reaction: General Procedure. A suspension of complexes $\mathbf{4 a}, \mathbf{4 b}$, or $\mathbf{4 c}(0.01 \mathrm{mmol})$ and $0.1 \mathrm{M} \mathrm{KOH}$ in ${ }^{i} \mathrm{PrOH}(2 \mathrm{ml})$ in degassed ${ }^{i} \mathrm{PrOH}(8 \mathrm{ml})$ was heated at $82^{\circ}$ under $\mathrm{N}_{2}$ for $1 \mathrm{~h}$. To the resulting soln. was added acetophenone $(120 \mathrm{ml}, 1 \mathrm{mmol})$ via a syringe. The temp. of the mixture was maintained constant at $82^{\circ}$ during the reaction, which was monitored in time via HPLC analysis (Daicel Chiralcel-OD column; flow rate $1.0 \mathrm{ml} / \mathrm{min}$; hexane, $\left.{ }^{\text {}} \mathrm{PrOH} 96: 4\right)$.

\section{REFERENCES}

[1] K. Wang, M. E. Goldman, T. J. Emge, A. S. Goldman, J. Organomet. Chem. 1996, 518, 55; A. Pape, M. Lutz, G. Müller, Angew. Chem., Int. Ed. 1994, 33, 281; C. S. Creaser, W. C. Kaska, Inorg. Chim. Acta 1978, 30, L325.

[2] a) R. M. Gauvin, H. Rozenberg, L. J. W. Shimon, D. Milstein, Organometallics 2001, 20, 1719; b) F. Liu, E. B. Pak, B. Singh, C. M. Jensen, A. S. Goldman, J. Am. Chem. Soc. 1999, 121, 4086; c) B. Rybtchinski, Y. Ben-David, D. Milstein, Organometallics 1997, 16, 3780; d) M. E. van der Boom, H.-B. Kraatz, L. Hassner, Y. Ben-David, D. Milstein, Organometallics 1999, 18, 3873.

[3] a) D. G. Gusev, F. M. Dolgushin, M. Y. Antipin, Organometallics 2001, 20, 1001; b) D. G. Gusev, M. Madott, F. M. Dolgushin, K. A. Lyssenko, M. Y. Antipin, Organometallics 2000, 19, 1734; c) B. Reinhart, D. G. Gusev, New J. Chem. 1999, 1; d) M. E. van der Boom, C. L. Higgitt, D. Milstein, Organometallics 1999, 18, 2413; e) M. E. van der Boom, S.-Y. Liou, Y. Ben-David, L. J. W. Shimon, D. Milstein, J. Am. Chem. Soc. 1998, 120, 6531; f) M. Gupta, C. Hagen, W. C. Kaska, R. E. Cramer, C. M. Jensen, J. Am. Chem. Soc. 1997, 119, 840; g) C. J. Moulton, B. L. Shaw, J. Chem. Soc., Dalton Trans. 1976, 1020.

[4] R. J. Cross, A. R. Kennedy, K. W. J. Muir, J. Organomet. Chem. 1995, 487, 227; A. R. Kennedy, R. J. Cross, K. W. J. Muir, Inorg. Chim. Acta 1995, 321, 195.

[5] a) J. Yao, W. T. Wong, G. Jia, J. Organomet. Chem. 2000, 598, 228; b) G. Jia, H. M. Lee, I. D. Williams, J. Organomet. Chem. 1997, 534, 173; c) T. Karlen, P. Dani, D. M. Grove, P. Steenwinkel, G. van Koten, Organometallics 1996, 15, 5687; d) H.-B. Kraatz, D. Milstein, J. Organomet. Chem. 1995, 488, 223; e) H. Rimml, L. M. Venanzi, J. Organomet. Chem. 1984, 260, C52; f) H. Rimml, L. M. Venanzi, J. Organomet. Chem. 1983, 259, C6.

[6] G. Zhu, M. Terry, X. Zhang, Tetrahedron Lett. 1996, 37, 4475; J. M. Longmire, X. Zhang, Tetrahedron Lett. 1997, 38, 1725.

[7] M. Gupta, C. Hagen, R. J. Flesher, W. C. Kaska, C. M. Jensen, J. Chem. Soc., Chem. Commun. 1996, 2083; M. Gupta, W. C. Kaska, C. M. Jensen, Chem. Commun. 1997, 461; C. M. Jensen, Chem. Commun. 1998, 2443.

[8] M. Ohff, A. Ohff, M. E. van der Boom, D. Milstein, J. Am. Chem. Soc. 1997, 119, 11687.

[9] a) P. Dani, T. Karlen, R. A. Gossage, S. Gladiali, G. van Koten, Angew. Chem., Int. Ed. 2000, 39, 743 ; b) D. Amoroso, A. Jabri, G. P. A. Yap, D. G. Gusev, E. N. dos Santos, D. E. Fogg, Organometallics 2004, $23,4047$.

[10] J. T. Singleton, Tetrahedron 2003, 59, 1837.

[11] M. E. van der Boom, D. Milstein, Chem. Rev. 2003, 103, 1759.

[12] M. Albrecht, G. van Koten, Angew. Chem., Int. Ed. 2001, 20, 3750. 
[13] F. Gorla, A. Togni, L. M. Venanzi, A. Albinati, F. Lianza, Organometallics 1994, 13, 1607; J. M. Longmire, X. Zhang, M. Shang, Organometallics 1998, 17, 4374.

[14] J. G. Donkervoort, J. L. Vicario, E. Rijnberg, J. T. B. H. Jastrzebski, H. Kooijman, A. L. Spek, G. van Koten, J. Organomet. Chem. 1998, 550, 463; J. G. Donkervoort, J. L. Vicario, J. T. B. H. Jastrzebski, W. J. J. Smeets, A. L. Spek, G. van Koten, J. Organomet. Chem. 1998, 551, 1.

[15] B. S. Williams, P. Dani, M. Lutz, A. L. Spek, G. van Koten, Helv. Chim. Acta 2001, 84, 3519.

[16] D. Morales-Morales, R. E. Cramer, C. M. Jensen, J. Organomet. Chem. 2002, 654, 44.

[17] a) P. Dani, T. Karlen, R. A. Gossage, W. J. J. Smeets, A. L. Spek, G. van Koten, J. Am. Chem. Soc. 1997, 119, 11317; b) P. Dani, M. Albrecht, G. P. M. van Klink, G. van Koten, Organometallics 2000, 19, 4468; c) M. Gagliardo, H. P. Dijkstra, P. Coppo, L. De Cola, M. Lutz, A. L. Spek, G. P. M. van Klink, G. van Koten, Organometallics 2004, 23, 5833.

[18] P. Dani, B. Richter, G. P. M. van Klink, G. van Koten, Eur. J. Inorg. Chem. 2001, 125.

[19] P. Dani, G. P. M. van Klink, G. van Koten, Eur. J. Inorg. Chem. 2000, 1465.

[20] H. P. Dijkstra, M. Albrecht, G. van Koten, Chem. Commun. 2002, 126.

[21] K. Marat, 'Spinworks', Version $2.0 \alpha$, University of Manitoba, Canada.

[22] H. P. Dijkstra, M. Albrecht, S. Medici, G. P. M. van Klink, G. van Koten, Adv. Synth. Catal. 2002, $344,1135$.

[23] O. Pàmies, J.-E. Bäckvall, Chem. Rev. 2003, 103, 3247; G. Csjernyik, K. Bogár, J.-E. Bäckvall, Tetrahedron Lett. 2004, 45, 6799.

[24] J.-P. Sutter, S. L. James, P. Steenwinkel, D. M. Grove, N. Veldman, A. L. Spek, G. van Koten, Organometallics 1996, 15, 941.

[25] P. T. Beurskens, G. Admiraal, G. Beurskens, W. P. Bosman, S. Garcia-Granda, R. O. Gould, J. M. M. Smits, C. Smykalla, 'The DIRDIF 97 Program System', Technical Report of the Crystallography Laboratory, University of Nijmegen, 1997, The Netherlands.

[26] A. Altomare, M. C. Burla, M. Camalli, G. L. Cascarano, C. Giacovazzo, A. Guagliardi, A. G. G. Moliterni, G. Polidori, R. Spagna, J. Appl. Crystallogr. 1999, 32, 115.

[27] G. M. Sheldrick 'SHELXL-97. Program for Crystal Structure Refinement', University of Göttingen, 1997, Germany.

[28] A. L. Spek, J. Appl. Crystallogr. 2003, 36, 7.

[29] H. D. Flack, Acta Crystallogr., Sect. A 1983, 39, 876. 